\title{
CHILDREN'S LITERATURE IN/AND TRANSLATION: THE OEUVRE AS CORPUS
}

\author{
Kirsten Malmkjær \\ University of Leicester, UK
}

\begin{abstract}
In this article, I argue that whereas Lewis Carroll builds the fantastic world of Alice's dreams primarily through narration, Hans Christian Andersen uses patterns of lexical choices that recur throughout his opus to build a universe divided solely in terms of a distinction between what is genuine and what is artificial; and this distinction is a central player in all of his work. Arguably, therefore, attention to Andersen's wider corpus, and to his use of lexis in it, are key to producing translations of Andersen's work that reflect its essence.

Keywords: Hans Christian Andersen; Lewis Carroll; "The princess on the pea”; Alitje in the dreamtime; Henry William Dulcken; Nancy Sheppard.
\end{abstract} leicester.ac.uk 


\section{Introduction}

In this article, I briefly contrast two authors, Hans Christian Andersen and Lewis Carroll both of whom who wrote "for children", who use identifiably different techniques to create their fictional worlds. I enclose "for children" in quotation marks, because as is well known and well rehearsed by several writers on Children's literature, and in fact by one of my authors himself, there is often an element of appeal to adults in children's literature as well as strong parental involvement in acquiring the works. Before the digital age, children rarely had the facility and wherewithal to procure their own reading material; and although the internet has made much reading material freely available for today's child, and despite the availability of literature for children in public libraries, I suspect that books, e.g., for reading aloud and for reading in bed, are still often acquired for a child by an adult. In any case, when my chosen authors were writing, there was no internet, and children were to a considerable degree dependent on their parents for entertainment of the kind that had to be paid for, including books. The point of my article is to show that of the different methods adopted by my chosen authors for creating a fictional world, one of them (Andersen) especially invites a translator to consider their individual translation choices in the context of the writer's oeuvre as a whole; because of the need to illustrate this, the majority of my article is devoted to the author who uses this technique.

I will begin with a brief discussion of the concept of Children's literature and of translations of such literature into English.

\section{Children's literature and my chosen authors}

According to the Wikipedia portal, "Children’s literature" (accessed 4.5.16):

Children's literature is literature written for and/or marketed towards a primarily juvenile audience. While some books are authored for a youthful audience, others become associated with children through marketing or tradition. Still others are "crossover" books, read by children and adults alike. Literature addressed directly to children arose in Western Europe in the late 17 th and early 18 th centuries, becoming a very profitable industry in the 19th century. It includes picture books, fairy tales, animal stories, school stories, science fiction, fantasy, series fiction, chapter books, children's poetry, and other genres. (https://en.wikipedia.org/wiki/ Portal:Children\%27s_literature)

I think that this is a sensible definition, although in the case of the two authors I shall be concerned with here, Hans Christian Andersen and Lewis Carroll, definition is not so much of an issue, since they both declared that they were writing for children (which does not necessarily mean that they were not addressing adults too).

The collections of stories that Andersen published during the years 18351842 all included the words, "fortalte for Børn", that is "told for children", even 
though in a set of "remarks" included in a collection published in 1863, Andersen indicates that he always had an adult readership in mind as well (see De Mylius 1995: 14-15). In the titles of collections of stories Andersen published from 1843 onwards, there is no mention of a projected child audience, and from 1850 onwards, the Danish term closest to the English "fairytale", "eventyr", was replaced or complemented by "historie", which means "story" (de Mylius 1995: 27).

As for Carroll's Alice books, they are probably only comprehensible in all their ironic, satirical, humorous glory by adults. Nevertheless, Carroll wrote the books about Alice in response to a direct request from Alice herself, who was then a child, (Hargreaves 1932, quoted in Gardner, 1960, p. 22, note 1), so in that sense the stories were certainly aimed at a child audience. Also, they arose from a series of stories that Carroll told Alice and her sisters on trips along the river Thames in Oxford.

Both sets of stories are a little out of the ordinary in that they have been translated numerous times into numerous languages, including, in Andersen's case, English. This places Andersen's stories in a special category. "Out of the $3 \%$ of all books published in the UK each year that are translated, only $1 \%$ are children's books" (Hallford and Zaghini 2005: 5). A later study (Donahaye 2012: 4) suggests that the percentage of books published in the UK that are translated is in fact "consistently greater than 4\%", but unfortunately, an even later Media Release, published 13th April 2015 by Literature Across Frontiers (http://www.lit-acrossfrontiers.org/new-translation-statistics-from-laf/) defends the 3\% view. Anyway, the number of translated books for children published in the UK is small.

The two authors that I have chosen to concentrate on, Lewis Carroll and Hans Christian Andersen, both build fictional worlds in their works, but they do it in rather different ways, and it is instructive to muse on that. Generalising, one might say that Carroll creates his world(s) by overt description, whereas Andersen creates his more covertly, by way of lexical choices. Andersen describes as well, but the essence of his worlds has to be teased out by way of special attention to the lexis, in my view, and that makes him more demanding on a translator than Carroll is. It is here that the notion of a writer's oeuvre as corpus becomes relevant to my argument, which is that to identify Andersen's technique, it is necessary to study the oeuvre as a whole, because his technique is accumulative; in Carroll's case, each instance of invention stands on its own. Therefore, a translator can be just about as creative with each Carroll example as she or he likes, without affecting any wholeness or unity that the individual cases come together to create--as long as the general flow of the story is not interrupted. It does not matter that the March Hare and the Mad Hatter with the Doormouse sitting between them fast asleep become the Horse and the Stockman with a Koala sitting between them fast asleep in Nancy Sheppard's Pitjantjatjara and English bilingual edition of Alitjinya ngura tjukurtjaranga / Alitje in the dreamtime. There are many changes of this kind in the Pitjantjatjara translation, but they all serve to maintain a fictional world for the aboriginal reader that is relevant and logical, within the confines of the story, given the physical context of the readership. They 
do not disrupt the fictional world created in the original as much as convert it to a fictional world that suits the new readers. More to the point, nor does it matter that the texts vary for example as follows (from Ch. 2):

\section{English}

"You ought to be ashamed of yourself," said Alice, "a great girl like you," (she might well say this), "to go on crying in this way! Stop this moment, I tell you!" But she went on all the same, shedding gallons of tears, until there was a large pool all round her, about four inches deep and reaching half down the hall.

\section{Pitjantjatjara (English gloss)}

"Now stop that! Why are you crying? A big girl like you" - she was indeed big - you'd better stop at once, at once, do you hear!" Thus Alitji spoke severely to herself. But she really couldn't stop crying, and went on shedding enormous tears which dripped on her legs and slipped down to the ground all around her, until there was a pool almost covering the floor.

Here, the differences seem unproblematic, even though the story theme around this passage involves Alice changing size repeatedly so that adjectives of size and terms indicating mass might be considered focal. In contrast, I have argued (Malmkjær 1993; 1995 a, b; 1996; 2003 a, b; 2004 a, b; 2007), and am going to argue here, that Andersen's patterned choices of lexis and syntax reflect the ethics and aesthetics of a fictional world that he builds largely by way of his lexical choices.

I do not want to imply that one of these writers, Carroll or Andersen, is accordingly better than the other, just that they work in different ways. It should come as no surprise that that means that the opportunities for creativity that they offer the translator are different; but it might come as a surprise that the more obviously inventive and fantastic of the two, Carroll, is in fact the less challenging to translate "loyally", in Nord's (1989/1997: 123) sense--at least as I see it. According to Nord, loyalty in translation amounts to a bilateral commitment on the translator's part-that is, it has to do with an attitude of the translator--to the first-written text and to the translation, as well as a bilateral commitment to both the author of the first-written text and to readers of the translation. This is a nice concept to employ to explain that the translation that stays closest to the firstwritten text linguistically may not be the one that most enhances the first-written text's afterlife, to borrow Benjamin's (1923) term. Sometimes, though, it may be the close translation that is most loyal.

As for the two writers: Lewis Carroll is the pen name of Charles Lutwidge Dodgson (1832-1898), a teacher of mathematics at Christ College, Oxford University. He was a keen photographer and wrote essays, political pamphlets and poetry (http://www.biography.com/people/lewis-carroll-9239598). Hans Christian Andersen (1805-1875) wrote prose, poetry and drama. He is best known, both in Denmark and elsewhere, for his stories, although his fame began with his three novels, which have the English titles (in Mary Howitt's translations, 
from intermediate German versions, all published in 1845) The Improvisatore, or, Life in Italy, and Only a Fiddler; and O.T., or, Life in Denmark. By the Author of the Improvisatore, or, Life in Italy. The popularity of these prepared the way for the enthusiastic reception of Howitt's selection of translations of the stories, published in 1846: Wonderful Stories for Children. By Hans Christian Anderson [sic], Author of 'The Improvisatore' etc. Since that introduction of the stories into English, new translations have appeared regularly.

\section{Analyses}

The text that I want to use to illustrate Andersen's lexical dexterity is "Prindsessen paa Ærten" (The princess on the pea), which Andersen published in 1835. It is a text of 368 word tokens of which 60 are nouns or compound nouns, and 20 are adjectives. Below, I list their closest English equivalents with the number of times they occur in the story:

\section{Nouns}

prince $\mathrm{x} 2$; princess/princesses $\mathrm{x}$ 12; world; something $\mathrm{x} 3$; evening; storm; thunder; lightening; rain x 2; knock; town-gate; king; God x 2; sight; weather; water; hair; clothes; toes; shoes; heels; queen; bedroom; bedclothes; pea $\mathrm{x} 4$; bottom; bed x 2; mattresses $\times 3$; eiderdown-quilts $\times 2$; night $\mathrm{x} 2$; morning; eyes; body; wife; Collection; story

\section{Adjectives}

rigtig/rigtige x 5; sad; virkelig x 3; dreadful; frightful x 2; old x 2; evil; whole x 2; hard; tender skinned; Royal

Among the combinations of the relatively few adjective tokens with the relatively more prolific noun tokens, we find the following combinations of adjective + noun:

\section{Adjective - Noun combinations}

Rigtig/rigtige princess(es) x 4; virkelig princess $\mathrm{x} 3$; dreadful storm; old king; evil weather; old queen; whole night; Royal Collection; rigtig story.

What we know so far, partly on the basis of this analysis and partly on the basis of background knowledge, is that:

- the most frequent noun tokens are forms of the lexical item PRINCESS (12);

- the most frequent adjective tokens are forms of the lexical item RIGTIG (5) 
- the most frequent $\mathrm{ADJ}+\mathrm{N}$ combination is of those two lexical items (4)

- $\quad$ PRINCESS is modified by one other adjective in this story, namely VIRKELIG

- This is the next most frequent adjective form in the story (3)

- The two adjectives RIGTIG and VIRKELIG fall within the same "semantic field": both indicate a quality of being a good example of a kind.

- The combination PRINCESS + RIGTIG/VIRKELIG is also focal semantically because the story is about finding a princess who has the characteristic(s?) the adjectives stand for: The prince wants a princess who is rigtig/virkelig.

- One other noun only, namely STORY is premodified by one of these adjectives, namely RIGTIG.

This raises two questions:

i. Do the two adjectives which are formally different but semantically similar differ in meaning in this story?

ii. What quality does the princess share with the story which allows both to be described as rigtig?

Looking in a dictionary will not help resolve these issues, because for both rigtig and virkelig, a dictionary will provide a selection of definitions (if it is monolingual) or translations (if it is bi-lingual) falling within the "good example of its kind"-field, most of which will work very well in each of the contexts in question. This is a reflection of the closeness in meaning of the two adjectives, of course, and it shifts the focus of inquiry sharply onto the prepositional phrase at the end of our first question: Do the two adjectives differ in meaning in this story?

Can this question be answered by looking at this story alone?

And do the many translations that exist of this story reflect the pattern of use of the adjectives in the original?

The last question is easy to answer, and the answer is no. Here is a selection of translations chosen by a number of translators:

Anon: $\quad$ real princess(es) $\times 6$; true story

Blegvad: $\quad$ real princess(es) $\mathrm{x} 7$; a story

Corrin: $\quad$ truly real princess; real princess(es) $\mathrm{x} 5$; true princess;

true story

Corrin and Corrin: truly real princess; real princess(es) x 6; real story

De Chatelain: $\quad$ real princess $\mathrm{x} 6$; real ones; real story

Dulcken: $\quad$ real princess(es) $\mathrm{x} 6$; real one; true princess; true story

Hersholt: $\quad$ real one; real Princess(es) x 5; a Princess; true story 
Haugaard: $\quad$ real one; real princess(es) x 5; real story

Kingsland: $\quad$ real princess(es) $\times 7$; true story

Lewis: $\quad$ real princess $\mathrm{x} 5$; the genuine article; fine story

Nunnally: $\quad$ real princess(es) $x$ 7; real story

Peachey: $\quad$ real Princess(es) x 7; "Was not this a lady of real delicacy"

Peulevé: $\quad$ genuine Princess; real Princess(es) x 6; good story

Spink: $\quad$ real princess(es) 7; real story

Wehnert: $\quad$ real Princess(es) x 7; true story

Obviously, none of the translators replicate the patterns of $\mathrm{ADJ}+\mathrm{N}$ use of the original.

Two translators, Corrin and Dulcken, use two adjectives and use one of them for the story as well as for the princess; Lewis and Peulevé also use two adjectives for the princess, but have a third for the story; Anon, Blegvad, Hersholt, Kingsland and Wehnert distinguish in their adjective use between the princess and the story; Corrin and Corrin, De Chatelain, Haugaard, Nunally, Peachey and Spink draw no distinction whatsoever.

Does this matter? And if so, to what does it matter? Perhaps looking elsewhere in Andersen's oeuvre can help to answer these questions, which would be helpful, since looking at this story alone will give us few clues. The prince modifies the object of his desire by way of both adjectives, which is not helpful. The princess herself reportedly uses only one of the adjectives about herself (virkelig), but then she speaks only once about the matter in question, and that in reported speech.

Are the two adjectives just elegant variations? Again, an obvious way to try to answer this question is to go and look at the rest of Andersen's work-to treat the oeuvre as a corpus--and such an excursion yields very interesting results (I report representative but select data, in an English gloss-type translation which leaves the adjectives in question, underlined, in Danish):

To begin with the adjective, "rigtig":

From The shepherdess and the chimney-sweep (1845)

Have you ever seen a rigtig old wooden cupboard, quite black with age and carved with intricate patterns of leaves?

From The puck at the grocer's (1853)

There was a rigtig student, he lived in the attic and owned nothing; there was a rigtig grocer, he lived on the ground floor and owned the whole house

In these examples "rigtig" seems to be used to indicate stereotypicality of the object to which they are applied, rather than essence, perhaps; especially the second example in which we have the stereotypically poor student and the stereotypically rich grocer. 
Moving on to the adjective "virkelig"

From The swineherd (1842)

"Fie Papa!" she said, "it isn't artificial, it is virkelig!"

From The nightingale (1844)

1. it was a little piece of artistry lying in a box, an artificial nightingale that was supposed to look like the live one but which was covered all over with diamonds, rubies and sapphires; as soon as it was wound up, the artificial bird could sing one of the pieces the virkelige one sang,

2. the virkelige nightingale sang in its own way, and the artificial bird was clockwork;

3. Then the artificial bird must sing alone. - It was as popular as the virkelige one, and besides it was much prettier to look at: it glittered like bracelets and brooches.

4. that it [the artificial bird] was better than the virkelige nightingale,

5. in the case of the virkelige nightingale you can never predict what is going to happen, whereas in the case of the artificial bird, everything is arranged in advance!

6. But the poor fishermen who had heard the virkelige nightingale said: "it [the artificial bird] sounds beautiful all right, and it does resemble it, but something is missing, I don't know what!"

From Holger Danske (1845)

and here is a likeness of him!"

And it cast its shadow right up the wall, even a little way along the ceiling, it looked as if it was the virkelige Holger Danske himself

In these data, virkelig is regularly opposed to terms indicating artificiality or artistry.

So these data suggest to me that Andersen uses the adjectives rigtig and virkelig to distinguish between that which either is a still life or which (merely) conforms to socially held values, norms and expectations (rigtig), and that which is genuinely and inherently what it purports to be (virkelig). Since this distinction is important thematically in much of Andersen's work, it is likely that the use of the adjectives is a deliberate way of supporting a theme lexically. In other words, the adjectives function for Andersen as specialised terms, which might be a reason for some translators to want to reproduce the kinds of patterns they enter into in the text.

I have suggested elsewhere (Malmkjær 2003) that one way of doing this might be to use "real" for rigtig and "genuine" for virkelig: According to the COBUILD 
dictionary, something "real" (sense 2.1.) "has all the characteristics or qualities that such a thing typically has" whereas "something which is genuine is real and exactly what it appears to be, and is not fake or an imitation".

In our focal story, this distinction is important: The prince is looking for the genuine (virkelig) article, as Naomi Lewis's translation has it, but he is rather unsure about how to recognise it when he sees it. The princess who presents herself claims to be it, but fails to conform to expectations on the surface and has to be tested. The test reveals that she possesses the sensitivity inherent in princesses. It is not clear that the prince, whose point of view predominates in the story, is any clearer towards the end of the story about the difference between the real and the genuine, since both adjectives are used for the princess in views attributed to him, and rigtig is the one he uses at the end ("he knew that he had a rigtig princess"); I take this to be a fine touch of irony. But it is significant that the princess herself is reported as claiming to be virkelig, that it is this claim that the queen (who is the seat of wisdom in the story, who knows a test for princess-hood) sets out to test, and that it is this quality that is said to be possessed by tender-skinned people. Finally, this is certainly a "real", stereotypical story with the expected, Proppian fairytale characters of king, queen, prince who goes out to look for a bride, and princess in it.

So it seems to me that the two terms, rigtig and virkelig, function as specialised terms in this text just as much as brake and accelerator might in texts about cars, and that it may be just as important to retain them in translation, although the consequences of not retaining them have less potential for physically impactful consequences than might be the case for brake and accelerator. This in turn may be why there is not a concentration on specialist terminology in literary translation. In fact, one could even speak of a blindness to it among literary translators, which can lead them to adopt the cavalier attitudes to literary terminology that we see exemplified in the translations cited here.

One objection might be raised to my argument for the meaning distinction between "rigtig" and "virkelig" that I have sought to draw here, namely that "The Princess and the Pea" is one of the earliest stories to be published, in 1835, whereas the other stories I have referred to were not published until 1842, 1844, 1845 and 1853. So it might be objected that it is unreasonable to argue that Andersen had the distinction in mind as early as 1835 . However, the distinction is also found in Andersen's novels which were published before the stories. For example, in Andersen's semi-autobiographical novel O.T. (1836), we find

\section{p. 27: the virkelige flowers (as opposed to young women)}

and the following examples from a description of a play, whose characters and scenes are being compared and contrasted with reality:

p. 151: there was a noise, as in the noisiest place in the virkelige deer garden ... and the scent of virkelige waffles emanated from the neighbouring shop ... where the entire botanizing party with their virkelige professor ... 
and the following example in which a woman who is not the speaker's sister is being compared to a woman who is his sister:

p. 229: She is not who he said! I will seek out my virkelige sister.

In contrast, the example below illustrates the use of the adjective "rigtig" to indicate stereotypicality:

p. 193: "Right Anders Peersen!" laughed all the girls, "We'll soon see if you're a rigtig man!"

It is also interesting to note that the same adjectives are used in Andersen's non-fiction in ways that reinforce the use in the stories. For example, in the travelogue, Et Besøg i Portugal 1866 (A Visit to Portugal 1866) they occur just once each in the following contexts:

Example (4) From Et Besøg i Portugal 1866

i. p. 187: two rigtig Danish red-thorns

ii. p. 199: a virkelig living human being [as opposed to a wooden figure]

This work is known for being full of references to how like Denmark Portugal is (!) (Dal 2002a: 280). Nevertheless, to call two thorn trees growing in Portugal "rigtig danske" (really Danish) strongly suggests that the adjective is being used in precisely the sense "being like" and not in the sense "being". In the case of the example with virkelig, the opposite holds: the term is being used to refer to a genuine person as opposed to a wooden figure. It is interesting that Andersen employs the adjectives in the stories, which are fiction, in the same way that he did in this more realistic narrative; this also, incidentally, supports the notion that he does not distinguish clearly between the genres.

In previous work (Malmkjær 1993; 1995 a, b; 1996; 2003 a, b; 2004 a, b; 2007), I have gone so far as to argue that there is just this one socially and ethically significant division in Andersen's fictional world that the two adjectives, "rigtig" and "virkelig", help to set up. This division between what is genuine and what is artificial is often expressed in his story lines, but it is strongly supported by a distinction not just between these adjectives, but between other pairs of lexical items also, that tend to be used alongside them. In contrast, a more traditional distinction between the secular and the divine is not only not maintained in Andersen's work, it is actively denied by way of juxtapositions of divine and secular vocabulary, again in support of the storylines.

Comparing the originals with translations in which the patterns of lexical choices that support the storylines are not maintained, while the storylines themselves remain constant (as far as this is possible when the lexis is changed), illustrates the role played by the patterns of lexical choices in styling the fictional universes in the two sets of text, the originals and the translations. I have chosen 
the translations by Henry William Dulcken to compare with the originals, for two reasons. First, Dulcken, unlike a number of other early translators, is on the whole very faithful to the originals so that when he does deviate from them, we can assume that this is done deliberately (a few errors notwithstanding). Secondly, Dulcken's is the most complete set of early translations, including 111 of the more than 160 stories that Andersen published in his lifetime. It is important to use the work of a translator who has translated a substantial number of the stories, for two reasons. First, it is possible for such a translator to have noticed the patterns I am interested in across a number of stories; and secondly, since my argument is that patterns of usage across stories (and other genres) create Andersen's universe, I need to see whether this patterning is reproduced in translations across a number of stories. It is regularity of translational choices that needs to be examined, not individual cases.

\section{Adjectives/adverbs - the distinction between the genuine and the artificial}

As well as the adjective/adverb pair rigtig(t) and virkelig(t) (the form with $-t$ being adverbial), Andersen used the adjective/adverb pair, nydelig( $(t)$ and $p æ n(t)$ to distinguish between phenomena that possess the essential properties of a type of which they are therefore genuine tokens (virkelig; pon) and phenomena which (perhaps merely) display inessential features commonly associated with the type (rigtig; nydelig).

The following example shows the adjective, virkelig in interaction with the other pair of distinction-drawing adjectives, nydelig and pon (cf. Malmkjær 2003a):

From The swineherd (1842)

"Oh, how nydeligt it is made!" said all the ladies-in-waiting.

"It is more than nydelig!" said the emperor, "it is poen!"

But the princess felt it and almost started crying.

"Fie Papa!" she said, "it is not artificial, it is virkelig!"

Here, the adverb, nydelig, which indicates artificiality, modifies a verb "gjøre" (here past perfect "gjort), that means "to make" (here "made"; underlined). The princess clearly indicates that she had mistakenly believed the item in question (a rose) to be manufactured. When she learns that it is genuine and not artificial, she dismisses it.

Further examples reinforce the connotations of genuineness as opposed to artificiality inherent (in Andersen's stories) in the modifier virkelig, as well as the connotations of artificiality inherent in Andersen's use of the adjectives nydelig and rigtig. His translator, Dulcken does not always follow suit. Dulcken's renderings are indicated by " $D$ " followed by the page reference to my version of Dulcken's tales; it is clear that they do not maintain the patterns that Andersen's texts display. 
From The nightingale (1844)

i. as soon as it was wound up, the artificial bird could sing one of the pieces the virkelige one sang,

D 294: So soon as the artificial bird was wound up, he could sing one of the pieces he really sang [this is a translation error]

Because of the translation error in this extract, and in spite of the emphasis on the artificial bird as artificial, the translation clearly does not convey the contrast between the artificial bird and the living bird.

ii. the virkelige nightingale sang in its own way, and the artificial bird was clockwork;

D: 294: the real Nightingale sang its own way, and the artificial bird sang waltzes [this is a translation error from "valser" which are turning, cylindrical bodies in machines]

iii. Then the artificial bird must sing alone. - It was as popular as the virkelige one, and besides it was much more nydelig to look at: it glittered like bracelets and brooches.

D 294: Now the artificial bird was to sing alone. It had just as much success as the real one, and then it was much handsomer to look at - it shone like bracelets and breastpins.

iv. that it [the artificial bird] was better than the virkelige nightingale, D 295: that it was better than a nightingale

Here, Dulcken arguably distinguishes the two birds more radically from each other by implying, by the use of the indefinite article, that the artificial bird is not a nightingale of any kind.

$\mathrm{v}$. in the case of the virkelige nightingale you can never predict what is going to happen, whereas in the case of the artificial bird, everything is arranged in advance!

D 295: with a real nightingale one can never calculate what is coming, but in this artificial bird, everything is settled.

vi. But the poor fishermen who had heard the virkelige nightingale said: "it [the artificial bird] sounds beautiful all right, and it does resemble it, but something is missing, I don't know what!"

D 295: But the poor fishermen who had heard the real Nightingale, said: "It sounds pretty enough, and the melodies resemble each other, but there's something wanting, though I know not what!"

\section{Creating and demolishing an undivided fictional universe}

Through his representation of relationships between humans, the divine, creatures in other states of being, and creatures of other ontological types, Andersen constructs a universe in the stories which is holistic except for the 
division between the genuine and the artificial that I have been talking about. For example, Johannes, in Reisekammeraten (The travelling companion) (1835), is able to speak quite naturally with his dead father and he assumes that his late father can speak directly to God (my translation):

But first he went to the churchyard to his father's grave, read the Lord's Prayer, and said: "Fare well my dear father! I will always be a good person, and then I am sure you will risk praying to the good God that things will go well for me!"

In Dulcken's translation (p. 47), this is not possible:

But first he went to the churchyard, to his father's grave, to say a prayer and to bid him farewell.

In the original, Johannes considers God to be a kissable being:

"Our good Lord! I could kiss you, because you are so good to us all and have given us all the beauty there is in the world!"

In Dulcken's translation (p. 51), no such thing is imaginable:

"How kind has heaven been to us all, to give us all the splendour that is in this world!"

In the original, Johannes prays to God at the same time as he is using other kinds of supernatural power, granted by an embodied dead person, to lift a spell from a princess who assumes bird-form at night because she is bewitched:

Johannes prayed devoutly to our Lord, and let the water pour over the bird for the third time.

In Dulcken's rendering (p. 59), the praying is removed, leaving the magic in sole charge of events:

John let the water close for the third time over the bird

As explained in Malmkjær (2003b; 2004a), it is not possible to account for Dulcken's reluctance, as evidenced in these examples, to use religiously loaded terminology with reference to the story genre, since there are about as many instances in which divine vocabulary is translated as there are instances in which it is not translated. Rather, as further examples testify, the two constraints on Dulcken's translation of such terms and expressions are (a) that religious terminology and references cannot be used in the vicinity of other supernatural 
forces; and (b) that a proper distance should be observed between God and humans, and between earth and Heaven, both physically and metaphorically. For example (from: “De vilde Svaner" 1838):

... then it seemed to her as if the tree branches above her moved aside and our Lord looked down at her with gentle eyes, and little angels peeped out from above his head and under his arms.

(Dulcken, p. 562):

Then it seemed to her as if the branches of the trees parted above her head, and mild eyes of angels looked down upon her from on high.

The differences between the scenes which these extracts present illustrate Dulcken's desire to keep divine and human beings well apart compared to the positions they occupy vis-à-vis one another in Andersen's universe. Dulcken's translation distances the dreaming girl physically further from the angels, who observe her from "on high", than the original's girl is from the Lord, who looks at her from among the trees and next to the angels. Metaphorically, the distance (in terms of familiarity, human characteristics and interpersonal interaction) between the divine and the human characters in the original scene is clearly less than in Dulcken's translation of the scene. Linguistically, these distances are reinforced by the absence from the translation of any mention of the deity.

\section{Implications for translation studies methodology}

Elsewhere (Malmkjær 2003b; 2004a), I have argued for a methodology for dealing with translations that I have called "translational stylistics". Translational stylistics is aimed at explaining why, given the way a source text is fashioned, its translation is fashioned as it is. It is important to carry out translational stylistics because of the reality changing powers of the translation enterprise. Unless we look at a translation in the context of its source, we may miss important hints concerning the motivation of the "intervening" translator.

Notes

1. According to wikipedia: A chapter book or chapterbook is a story book intended for intermediate readers, generally age 7-10. Unlike picture books for beginning readers, a chapter book tells the story primarily through prose, rather than pictures. Unlike books for advanced readers, chapter books contain plentiful illustrations. The name refers to the fact that the stories are usually divided into short chapters, which provide readers with opportunities to stop and resume reading if their attention spans are not long enough to finish the book in one sitting. Chapter books are usually works of fiction of moderate length and complexity (https:// en.wikipedia.org/wiki/Chapter_book; accessed 18.5.2016) 


\section{References}

Benjamin, Walter (1923). 'The Task of the Translator' [introduction to Charles Baudelaire,

Tableaux Parisiens, trans. Benjamin]. Trans. Harry Zohn. In Benjamin, Walter Illuminations. 1970. London: Collins (Fontana), 1973. 69-82.

Dal, E. (2002). Notes to Et Besoeg i Portugal 1866 (A visit to Portugal 1866) pp.

276-281 in $H$.

C. Andersen: Rejseskitser 1826-1872; Billedbog uden Billeder; Et Besoeg i Portugal 1866 Edited by Erik Dal. Copenhagen: Borgen.

Donahaye, Jasmine. (2012). Three percent? Publishing data and statistics on translated literature in the United Kingdom and Ireland. Wales: Aberystwyth University.

Dreyer, Kirsten. (2001). H. C. Andersen of Jonas Collin den yngre: En brevveksling 1855-1875. Copenhagen: Museum Tusculanums Forlag.

Even-Zohar, Itamar. (1971). An Introduction to a theory of literary translation. Doctoral dissertation. Tel Aviv: Tel Aviv University (in Hebrew with a summary in English).

(1978). Papers in historical poetics. Tel Aviv: The Porter Institute for Poetics and Semiotics.

Gardner, Martin. (1960). The Annotated Alice. Harmondsworth: Penguin Books.

Hallford, Deborah and Zaghini, Edgardo (eds). (1995). Outside In: children's books in translation. Chicago IL: Millet Publishing.

Hargreaves, Caryl. (1932). Alice's Recollections of Carrollian Days As Told to Her Son Caryl Hargreaves. The Cornhill Magazine, July 1932, pp. 1-2.

Levý, Jirí. (1969). [1963]. Die Literarische Übersetzung - Theorie einer

Kunstgattung,

tr. Walter Schamchula. Frankfurt am Main and Bonn: Athenaum.

Malmkjær, Kirsten. (1993). Stylistics in translation teaching. Perspectives: Studies

in Translatology 1.61-8.

(1995). Wilde Versions of Hans Christian Andersen's stories

Working papers in English and Applied Linguistics II. The University of

Cartrinidgtion and psycholinguistics'. In M. Baker, G. Francis and E. Tognini-

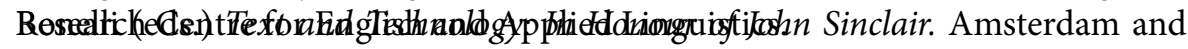
Malmiladelphia: John Benjamins Publishing Co.ppp. 213-232.

Collocatib995a: 'Translating the real story'. In J.A. Payne (ed.) Linguistic Approaches to Literature. English Language Research, University of Birmingham, pp. 170-184.

. 1995b: 'What's in an adjective?: Using cross-textual patterns of collocation in translating' Norwich Papers in Languages, Literatures and Cultures 3: 44-54.

1996: 'Who walked in the emperor's garden: The translation of pronouns in Hans Christian Andersen's introductory passages'. In G. Anderman and C. Banér (eds) Proceedings of the Tenth Biennial Conference of the British Association of Scandinavian Studies. The University of Surrey, Department of Linguistics and

International Studies, pp. 77-86.

2003a 'On a pseudo-subversive use of corpora in translator training'. In Federico Zanettin, Silvia Bernardini and Dominic Stewart (eds) Corpora in Translator Education. Manchester: St. Jerome, pp. 119-134. 
2003b 'What happened to God and the angels: An exercise in translational stylistics'. Target 15(1): 39-62.

. 2004a 'Censorship or error: Mary Howitt and a problem in descriptive TS. In (ed. with Gyde Hansen and Daniel Gile. Translation Studies: Claims, Changes and Challenges. Selected papers from the EST Congress, Copenhagen 2001. Amsterdam and Philadelphia: John Benjamins. pp. 141-155.

2004b 'Translational Stylistics'. Language and Literature 13(1): 13-24

Malmkjær, Kirsten and Carter, Ronald. (2002). Stylistics. Kirsten Malmkjær, ed. The

Linguistics encyclopedia, second edition. (pp. 510-520) London and New York: Routledge (first edition 1991).

Mylius, Johan de. (1993). H.C. Andersen - Liv og Vork (H.C. Andersen - Life and work). Copenhagen: Aschehough.

(1995). Hr Digter Andersen: Liv, Digtning, Meninger (Mr Author Andersen: Life, Authorship, Opinions). Copenhagen: Gad.

Nord, Christiane. (1989). 'Loyalität statt Treue. Vorschläge zu einer funktionalen Übersetzungstypologie.' Lebende Sprachen XXXIV(3): 100-105. . (1997). Translating as a purposeful activity. Functionalist approaches explained. Manchester: St. Jerome.

Oittinen, Riitta. (2000). Translating for children. New York and London: Garland Publishing.

Reiss, Katarina and Hans Josef Vermeer. (1984). Grundlegung einer allgemeine

Translationstheorie. Tübingen: Niemeyer.

Short, Michael. (1994). "Understanding Texts: Point of view”. Gillian Brown, Kirsten

Malmkjær, Alastair Pollitt and John Williams, eds. Language and understanding. Oxford, Oxford University Press.

Toury, Gideon (1977). Translational norms and literary translation into Hebrew, 19301945. Tel Aviv: The Porter Institute for Poetics and Semiotics.

. (1980). In Search of a theory of translation. Tel Aviv: The Porter Institute for Poetics and Semiotics.

(1995). Descriptive translation studies and beyond. Amsterdam and

Philadelphia: John Benjamins.

Vermeer, Hans Josef. (1978). "Ein Rahmen für eine allgemeine Translationstheorie". Lebende Sprachen 23. 99-102.

. (1983). Aufsatze zur Translationstheorie. Heidelberg: Groos.

(1986). Voraussetzungen für eine Translationstheorie: Einige Kapitel Kulturund Sprachtheorie. Heidelberg: Groos. 